\begin{tabular}{|lll|}
\hline Diterima & $:$ & 13 Januari 2020 \\
Direvisi & $:$ & 4 Mei 2020 \\
Disetujui & $:$ & 26 Juni 2020 \\
Diterbitkan & $:$ & 27 Juni 2020 \\
\hline
\end{tabular}

\title{
FAKTOR-FAKTOR YANG BERPENGARUH TERHADAP PROSES SELF- DIRECTED LEARNING WANITA KARIR DI KOTA TASIKMALAYA
}

\author{
Lesi Oktiwanti ${ }^{1}$, Lulu Yuliani ${ }^{2} \&$ Dede Nurul Qomariah $^{3}$ \\ email: lesioktiwanti@unsil.ac.id'1, luluyuliani@unsil.ac.id², \\ dnurul@unsil.ac.id ${ }^{3}$ \\ Program Studi Pendidikan Masyarakat Universitas Siliwangi
}

Jalan Siliwangi No. 24, Kahuripan, Kec. Tawang, Tasikmalaya, Jawa Barat 46115

\begin{abstract}
Abstrak: Modernisasi dan globalisasi mengharuskan wanita karir mampu membagi peran baik dalam urusan keluarga maupun dalam karirnya. Upaya yang dapat dilakukan oleh wanita karir guna menghadapi berbagai perubahan yang terjadi salah satunya yakni belajar mandiri. Belajar mandiri atau dikenal dengan self-directed learning (SDL) merupakan suatu proses dimana individu mengambil inisiatif dengan atau tanpa bantuan orang lain dalam memenuhi kebutuhan belajarnya. Tujuan penelitian ini adalah untuk menentukan dan mendeskripsikan pengaruh dimensi person dan konteks terhadap dimensi proses belajar mandiri pada wanita karir. Penelitian ini menggunakan metode survei melalui pendekatan kuantitatif dengan populasi sebanyak 4024 wanita karir dengan sampel 100 orang $(\alpha=0,1)$ yang diambil secara simple random sampling di sepuluh Kecamatan di Kota Tasikmalaya. Penelitian ini dilakukan pada Bulan April hingga Oktober 2019. Hasil penelitian menunjukkan bahwa person dan konteks berpengaruh sebesar $65,8 \%$ terhadap proses belajar mandiri wanita karir di Kota Tasikmalaya. Dukungan Konteks pada proses belajar mandiri lebih tinggi pengaruhnya dibandingkan dengan kemampuan personal wanita karir. Wanita karir yang memiliki kemampuan personal yang bagus jika didukung oleh konteks yang memadai akan membuat proses belajar mandiri wanita karir optimal dalam meningkatkan profesionalisme kerja dan ketahanan keluarganya. Dukungan konteks ini khususnya dukungan keluarga, kebijakan organisasi, dan kebijakan pemerintah. Rekomendasi atas penelitian ini yakni: a) perlu adanya dukungan dan kerjasama dari pihak keluarga, instansi dan pemerintah dalam memfasilitasi proses belajar mandiri yang dilakukan oleh wanita karir; b) perlu adanya penataan serius terkait kebijakan instansi dan pemerintah yang mendukung peran wanita karir sebagai pekerja maupun sebagai ibu dan istri.
\end{abstract}

Kata-kata Kunci: konteks, person, self-directed learning, wanita karir

\section{FACTORS AFFECTING THE SELF-DIRECTED LEARNING PROCESS OF CAREER WOMEN IN TASIKMALAYA CITY}

\begin{abstract}
Modernization and globalization require that career women are able to share roles both in family matters and their careers. One of the efforts that can be done by career women to deal with the occurrence of various changes is self-directed learning ( $S D L)$. SDL is a process in which individuals take initiative with or without the help of others in meeting their learning needs. The purpose of this study is to determine and describe the influence of person and context dimensions on the career women' SDL process. This study used survey method through a quantitative approach with population of 4024 career women and 100 people as sample $(\alpha=0.1)$ which taken by simple random sampling in ten districts in the City of Tasikmalaya. This research was conducted in April to October 2019. The results showed that the person and context affected $65.8 \%$ of the learning process of career women' SDL in Tasikmaya
\end{abstract}


Faktor-faktor yang Berpengaruh...

City. Context Support in the self learning process is more influential than the personal abilities of career women. Career women who have good personal abilities if supported by adequate context will make the process of their SDL optimal in improving work professionalism and family endurance. This context support specifically are family support, organizational and government policy. Recommendations for this research are: a) the need for support and cooperation from families, agencies and governments in facilitating career women' $S D L ; b$ ) the need for a serious arrangement related to agency and government policies that support the role of career women as workers as well as mothers and wives.

Keywords: career woman, context, person, self-directed learning

\section{PENDAHULUAN}

Ledakan pengetahuan dan perkembangan teknologi yang pesat telah menjadi tantangan utama bagi manusia untuk mengikuti ledakan pengetahuan dan inovasi teknologi. Kesulitan dalam memprediksi kemungkinan perubahan yang disebabkan oleh ledakan pengetahuan membuat pembelajar tidak siap untuk memenuhi tuntutan masa depan. Tuntutan ini diantaranya adalah a) rasa ingin tahu dan keinginan untuk tahu, b) kreativitas dalam menumbuhkan ide / solusi inovatif, c) keinginan untuk berpikir dan merefleksikan masalah, d) kemampuan untuk berbagi pemikiran sendiri dengan orang lain , e) menerima kritik dan mengembangkannya, f) kemampuan untuk memecahkan masalah secara kreatif, yang mengarah pada pendapat dan keputusan yang berpengetahuan, g) kemampuan untuk berpikir secara logis, h) menjadi mediator perubahan konstan, i) pengembangan diri berkelanjutan dan kemampuan untuk belajar sendiri, j) kemampuan untuk berpartisipasi dalam pengalaman belajar-mengajar yang interaktif, k) diarahkan sendiri, I) kemampuan untuk menempatkan pengetahuan ke dalam konteks kehidupan nyata dan terakhir, m) menjadi pembelajar abad ke-21 yang belajar dari inkuiri, desain, dan kolaborasi (Verster, Mentz \& Du Toit-Brits, 2018).

Pembelajar di abad ke-21 membutuhkan keterampilan belajar yang akan mempersiapkan mereka untuk berkolaborasi dengan orang lain di tingkat global. Menurut pendapat Louws, Meirink, Van Veen \& Van Driel (2017), Guglielmino (2013) dan Verster, Mentz \& Du Toit-Brits (2018) bahwa dunia yang berubah terkait dengan revolusi digital di mana kemandirian diri dan SDL telah menjadi vital. Dalam dunia yang terus berubah ini, pembelajar harus belajar untuk lebih mandiri, dalam persiapan tantangan pekerjaan dan kehidupan di abad ke-21. Sebagai hasil dari tingkat perubahan yang belum pernah terjadi sebelumnya yang kita hadapi dalam semua aspek kehidupan kita, pendidikan formal dan pelatihan tidak lagi secara efektif membantu menghadapi keinginan belajar di masa depan (Douglass \& Morris, 2014). Self-directed learning membantu masyarakat untuk menghadapi keinginan belajar seumur hidup di masa depan, sebagai sarana unggulan untuk membiasakan diri dengan perubahan, yang meliputi ledakan pengetahuan, karena dapat mendukung mereka untuk merespons dengan cara yang mencapai subjektivitas dan kepositifan mereka dan dapat memberdayakan mereka untuk menjadi mandiri dalam tindakan mereka (Attard, Di loio, Geven \& Santa, 2010; Imants, Wubbels \& Vermunt, 2013).

Ledakan pengetahuan pada abad ke 20 seiring dengan modernisasi yang terjadi juga menyebabkan terjadinya peningkatan besar dalam partisipasi angkatan kerja perempuan di berbagai negara (Arcarons, 2018; Park, Zhan \& Choi, 2019) sebagai akibat adanya ekspansi pendidikan bersamaan dengan munculnya kesadaran terhadap gender di seluruh dunia. Sama halnya di Indonesia perkembangan angka partisipasi perempuan bekerja semakin bertambah. Berdasarkan data terakhir diperoleh informasi bahwa tingkat partisipasi angkatan kerja perempuan sebesar 55,44 persen dari total populasi usia produktif perempuan Indonesia (BPS, 2018). Hal ini memberikan indikasi bahwa adanya kenaikan potensi ekonomi dari sisi pasokan (supply) tenaga kerja perempuan yang berkontribusi didalamnya. Kondisi ini menuntut tanggungjawab ganda perempuan selain sebagai pekerja juga sebagai istri dan ibu. Sebagian perempuan melakukan tugas menjadi ibu dan bekerja di luar rumah secara bersamaan, baik karena pilihan ataupun kebutuhan hidup (Park, Zhan \& Choi, 2019). Penelitian terdahulu melaporkan bahwa banyak perempuan yang bekerja mengalami kesulitan menyeimbangkan tuntutan pekerjaan dan keluarga misalnya dalam membesarkan anak-anak mereka (Gilbert \& Terrell, 2013) sehingga cenderung kesulitan menghadapi jam kerja yang menyita. Memperkuat temuan sebelumnya bahwa perempuan yang bekerja lebih sering mengalami tantangan terkait pengasuhan 
anak dibandingkan dengan ibu yang tidak bekerja (Moilanen, May, Räikkönen, Sevón \& Laakso, 2016).

Perempuan bekerja di sisi lain rentan mengalami konflik peran yang memicu stressor dalam keluarga dan berujung pada kerentanan keluarga. Pada satu sisi ia dituntut bertanggungjawab dalam melakukan pekerjaannya sebaik mungkin, di sisi lain ia harus mengatur urusan domestik keluarganya (suami, anakanak dan urusan rumah tangga lainnya). Kondisi ini memerlukan kesadaran dari semua anggota keluarga untuk saling memahami pembagian peran dalam keluarga sehingga ketahanan keluarga tetap terjaga. Menurut Lennon \& Heaman (2015) ketahanan keluarga mengacu pada kemampuan kelompok keluarga untuk beradaptasi dengan keadaan yang menantang. Tinggal di lingkungan perkotaan terkadang memicu stres bagi keluarga sehingga bagi keluarga yang tinggal di pusat kota, konsep ketahanan memiliki makna penting.

Belajar mandiri dianggap sebagai salah satu cara mengarahkan diri dalam menghadapi berbagai tantangan hidup perempuan agar tetap stabil baik dalam keluarga maupun dalam lingkungan kerjanya. Oleh karena itu berangkat dari konsep tersebut, maka rumusan masalah penelitian ini yakni faktor-faktor apa saja yang berpengaruh terhadap belajar mandiri (self-directed learning) atau yang dikenal dengan SDL.

Tujuan penelitian ini adalah untuk menentukan dan mendeskripsikan faktor-faktor yang berpengaruh terhadap belajar mandiri (self-directed learning). Dengan batasan masalah yakni: mendeskripsikan gambaran empiris self-directed learning wanita karier di Kota Tasikmalaya; mendeskripsikan dan menentukan pengaruh dimensi person dan context terhadap dimensi proses belajar mandiri wanita karier di Kota Tasikmalaya, dan mendeskripsikan faktor yang paling berpengaruh terhadap proses belajar mandiri wanita karir di Kota Tasikmalaya.

Belajar mandiri (self-directed learning) merupakan salah satu upaya preventif yang dapat dilakukan individu dalam menghadapi stressor keluarga. Belajar mandiri dipandang sebagai proses dimana individu mengambil inisiatif, dengan atau tanpa bantuan orang lain dalam mendiagnosis kebutuhan belajar mereka, merumuskan tujuan, mengidentifikasi sumber daya manusia dan materi untuk belajar, memilih dan menerapkan strategi pembelajaran yang sesuai, dan mengevaluasi hasil pembelajaran (Walsh, 2017). Sebagai tambahan, individu yang mampu mengarahkan diri sendiri dalam belajar dapat menampilkan otonomi moral dan beragam karakteristik emosional dan intelektual (Murray, 2015). Pengarahan diri berarti bahwa individu dapat mengambil seluruh tanggung jawab dalam proses pembelajaran (Merriam \& Brockett, 2007; Murray, 2015). Disadari maupun tidak bagi seorang perempuan, ia akan dapat berkerja secara maksimal apabila urusan domestik (kesehatan anak terjaga, komunikasi dengan suami terjalin dengan baik, dlI) dapat dikendalikan. Hal ini juga merupakan suatu gambaran bahwa keluarga sangat berperan penting dalam mendukung kemajuan karir perempuan bekerja.

Sedangkan menurut Ayyildiz \& Tarhan (2015) konsep belajar mandiri berhubungan dengan konsep pengendalian diri, kecukupan diri dan pengendalian diri. Pengendalian diri penting dalam belajar mandiri sehingga mengharuskan seseorang untuk memahami diri mereka sendiri dengan lebih baik. Hal ini tentu sejalan dengan kemampuan dalam mengelola emosi dalam keluarga. Inti dari belajar mandiri adalah gagasan bahwa pelajar mengambil kendali atas pembelajarannya sendiri dengan mengambil tanggung jawab dan memutuskan apa dan bagaimana sesuatu dipelajari (Merriam \& Bierema, 2013).

Dalam studinya Bijker, Klink \& Boshuizen (2010) mempelajari konstruk yang mempengaruhi self-efficacy, kemampuan belajar mengatur diri sendiri, kemampuan akademik dan karir dalam proses karir individu dewasa. Hasil yang diperoleh melalui model persamaan struktural menunjukkan bahwa pembelajaran self-directing adalah sistem dua dimensi, dan self-regulating dan self-efficacy bertindak sebagai prediktor signifikan pembelajaran self-directing. Selfdirected learning adalah kemampuan belajar mandiri yang dimiliki oleh setiap orang yang mungkin berbeda antar setiap individu karena perbedaan dalam jenis kelamin, pendidikan, pengalaman, serta latar belakang keluarga masing-masing. Self-directed learning itu sendiri merupakan konsep yang telah dikenalkan oleh Hiemstra \& Brockett (2012: 158) yang dikenal dengan model PPC (The Person Process Context) sebagaimana ditunjukkan dalam (gambar 1) berikut ini:

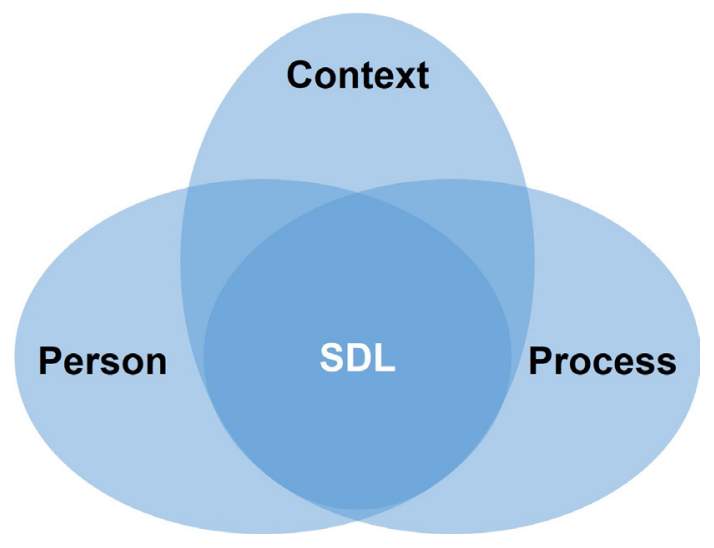

Gambar 1. The Person Process Context (PPC) Model: A $21^{\text {st }}$ Century Vision for Self Directed Learning (SDL) 
Model PPC di atas (Gambar 1.) merupakan hasil dari pengembangan model PRO (Personal Responsibility Orientation), yang mengkombinasikan pengalaman dan pengembangan literatur SDL yang telah dilakukan oleh Hiemstra dan Brockett selama 20 tahun. Hal tersebut penting untuk dikemukakan kembali bahwa elemen dasar dalam SDL tidak hanya orang atau pembelajar, tetapi juga termasuk proses belajar mengajar dan konteks sosial. Hiemstra \& Brockett (2012, hlm. 158) mengemukakan indikator ketiga elemen SDL dapat dilihat pada tabel di bawah ini:

Tabel 1.

Model PPC Hiemstra (The Person, Process, Context)

\begin{tabular}{c}
$\begin{array}{c}\text { Model PPC } \\
\text { Hiemstra }\end{array}$ Indikator \\
\hline
\end{tabular}

\begin{tabular}{ll}
\hline Person & Kreativitas \\
(Person) & - Refleksi diri secara kritis \\
& - Sikap antusias \\
& - Mengalaman hidup \\
& - Latar belakang pendidikan \\
& - Kepercayaan diri \\
& Konsep diri \\
\hline
\end{tabular}

\begin{tabular}{ll}
\hline Proses & $\cdot$ Gaya belajar \\
Process $)$ & $\cdot$ Perencanaan \\
& $\cdot$ Pengorganisasian \\
& $\cdot$ Kemampuan mengevaluasi \\
& teknologi \\
\hline Konteks & $\cdot$ Budaya \\
$($ Context $)$ & $\cdot$ Kekuatan \\
& $\cdot$ Lingkungan belajar \\
& $\cdot$ Finansial \\
& $\cdot$ Gender \\
& $\cdot$ Iklim belajar \\
& $\cdot$ Kebijakan organisasi \\
& $\cdot$ Kebijakan politik \\
& Orientasi seksual \\
\hline
\end{tabular}

Berdasarkan (tabel 1) di atas diperoleh gambaran bahwa dinamika hubungan antara ketiga elemen tersebut merupakan pengaruh utama pada SDL. Dalam model PPC di atas, merupakan situasi yang optimal untuk SDL agar menjadi efektif jika pembelajar, proses dan konteks berjalan seimbang.

\section{METODE PENELITIAN}

Penelitian ini menggunakan metode deskriptif survei dengan pendekatan penelitian kuantitatif. Penelitian ini dilakukan sejak Bulan April sampai dengan Bulan Oktober 2019. Penelitian ini dilakukan pada sepuluh kecamatan di Kota Tasikmalaya dengan subjek penelitiannya yaitu wanita yang bekerja pada instansi baik pemerintah maupun non pemerintah dengan jumlah populasi sebanyak 4.024 orang.

Teknik pengumpulan data dalam penelitian ini dilakukan dengan menggunakan teknik simple random sampling. Berdasarkan hasil sampling dari 10 kecamatan dengan menggunakan rumus Slovin (e $=0,1$ atau tingkat kesalahan 10\%) (Sevilla, C.G. et. al (2007).

Keterangan :

$$
n=\frac{N}{1+N e^{2}}
$$

$\mathrm{n}$ : Ukuran sampel

$\mathrm{N}$ : Ukuran populasi

e : error tolerance atau tingkat kesalahan

Maka jumlah sampel yang ditetapkan dengan pembulatan adalah sebanyak 100 orang responden. Teknik penelitian yang digunakan dalam penelitian ini yaitu melalui angket dengan data tambahan dari dokumentasi.

Analisis data dalam penelitian ini dilakukan dengan menerapkan teknik analisis jalur (path analysis) menggunakan tiga indikator, yaitu person dan proses SDL sebagai variabel bebas, context sebagai variabel terikat. Pengolahan data dibantu dengan menggunakan program SPSS 16. Diagram jalur pengaruh person dan context terhadap process self-directed learning wanita karir di Kota Tasikmalaya dapat dilihat pada (gambar 2) di bawah ini:

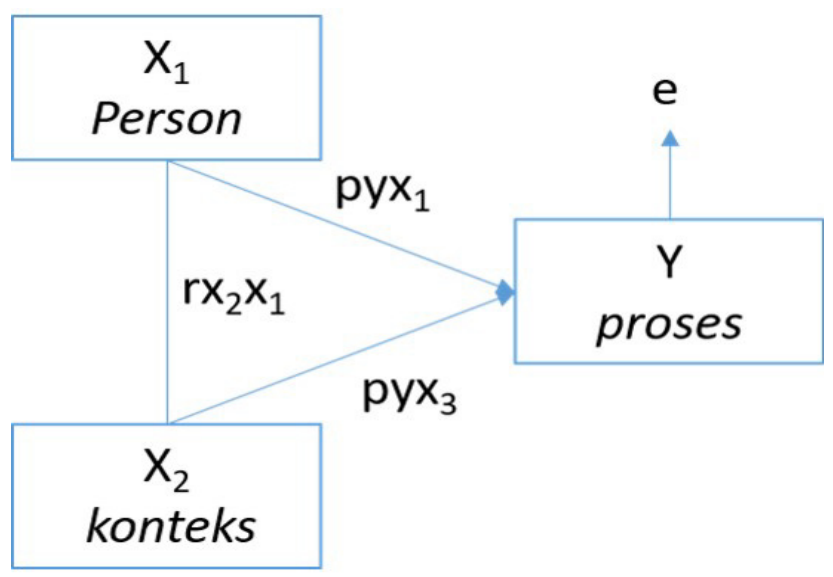

Gambar 2. Diagram Jalur Pengaruh $\mathrm{X} 1$ dan $\mathrm{X} 2$ terhadap $Y$ 


\section{HASIL DAN PEMBAHASAN}

\section{Hasil Penelitian}

Berikut ini adalah kondisi objektif dari responden penelitian yang diperoleh dari hasil pengolahan data. Data usia wanita karir yang menjadi responden penelitian ini adalah wanita karir yang pada umumnya berada pada usia produktif, yang didominasi oleh angkatan usia 31-40 tahun, yakni sebanyak 44 orang.

Tabel 2.

Usia Responden Penelitian

\begin{tabular}{cc}
\hline Usia Wanita Karir & Jumlah \\
\hline $21-30$ & 28 \\
$31-40$ & 44 \\
$41-50$ & 20 \\
$51-60$ & 7 \\
$61-70$ & 1 \\
\hline Jumlah Total & $\mathbf{1 0 0}$ \\
\hline
\end{tabular}

Data tingkat pendidikan wanita karir yang menjadi responden penelitian adalah paling banyak lulus sarjana yakni sebanyak 46 orang.

Tabel 3.

Tingkat Pendidikan Responden Penelitian

\begin{tabular}{cc}
\hline Tingkat Pendidikan Wanita Karir & Jumlah \\
\hline SMP & 7 \\
SMA-SMK & 15 \\
D1-D3 & 17 \\
S1 & 46 \\
S2-S3 & 15 \\
\hline Jumlah Total & $\mathbf{1 0 0}$ \\
\hline
\end{tabular}

Data usia suami, pada wanita karir didominasi hampir sama dengan usia wanita karir, yakni 31-40 tahun yakni sebanyak 44 orang.

Tabel 4.

Usia Suami Responden Penelitian

\begin{tabular}{cc}
\hline Usia Suami Wanita Karir & Jumlah \\
\hline $21-30$ & 18 \\
$31-40$ & 44 \\
$41-50$ & 20 \\
$51-60$ & 13 \\
$61-70$ & 5 \\
\hline Jumlah Total & $\mathbf{1 0 0}$ \\
\hline
\end{tabular}

Jumlah anak yang telah dimiliki oleh wanita karir paling banyak adalah tiga orang, yakni sebanyak 39 orang dan hanya 2 orang yang memiliki anak lebih dari 3 orang.
Tabel 5.

Jumlah Anak Responden Penelitian

\begin{tabular}{cc}
\hline Jumlah Anak & Jumlah \\
\hline 0 & 12 \\
1 & 29 \\
2 & 39 \\
3 & 18 \\
$>3$ & 2 \\
\hline Jumlah Total & $\mathbf{1 0 0}$ \\
\hline
\end{tabular}

Dilihat dari Usia pernikahan wanita karir, terdapat 26 pasangan yang relatif baru, dan 43 pasangan berada pada masa usia pernikahan pertengahan atau 6-15 tahun.

Tabel 6.

Usia Pernikahan Responden Penelitian

\begin{tabular}{cc}
\hline Usia Pernikahan (Tahun) & Jumlah \\
\hline$<5$ & 26 \\
$6-10$ & 21 \\
$11-15$ & 22 \\
$16-20$ & 9 \\
$21-25$ & 12 \\
$>26$ & 10 \\
\hline Jumlah Total & 100
\end{tabular}

Dilihat dari pekerjaan wanita karir, paling banyak didominasi oleh wanita yang berprofesi sebagai guru, yakni sebanyak 35 orang.

Tabel 7.

Jenis Pekerjaan Responden Penelitian

\begin{tabular}{lc}
\hline \multicolumn{1}{c}{ Jenis Pekerjaan } & Jumlah \\
\hline Dosen & 11 \\
Guru & 35 \\
Wiraswasta & 28 \\
PNS & 23 \\
\hline \multicolumn{2}{r}{ Jumlah Total } \\
\hline
\end{tabular}

Sedangkan untuk pekerjaan suami, paling banyak merupakan wiraswasta, yakni sebanyak 56 orang.

Tabel 8.

Jenis Pekerjaan Suami Responden Penelitian

\begin{tabular}{lc}
\hline \multicolumn{1}{c}{ Jenis Pekerjaan Suami } & Jumlah \\
\hline Anggota DPRD & 1 \\
BUMN & 2 \\
Wiraswasta & 56 \\
Dosen & 4
\end{tabular}

VISI : Jurnal IImiah PTK PNF - Vol. 15 No. 1, Juni 2020 


\begin{tabular}{lc} 
Guru & 11 \\
PNS & 20 \\
Wirausaha & 6 \\
\hline \multicolumn{1}{c}{ Jumlah Total } & $\mathbf{1 0 0}$ \\
\hline
\end{tabular}

\section{Deskripsi Self-directed Learning Wanita Karir} di Kota Tasikmalaya

Deskripsi penelitian tiap variabel akan diperinci pada (gambar 3 ) di bawah ini:

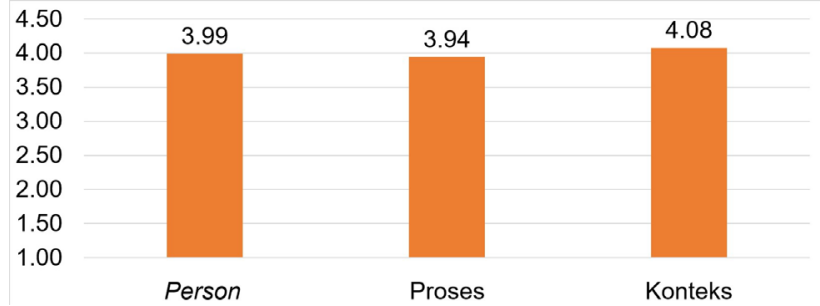

Gambar 3. Rata-Rata Skor Dimensi Person, Proses dan Konteks pada Variabel Self-Directed Learning Wanita Karir di Kota Tasikmalaya

Gambar 3 di atas menunjukkan bahwa rata-rata nilai tertinggi SDL wanita karir di Kota Tasikmalaya secara berturut-turut adalah konteks yakni 4,08 diikuti oleh person $(3,99)$ dan terakhir proses $(3,94)$. Berdasarkan data tersebut dapat diketahui bahwa wanita karir di Kota Tasikmalaya memiliki person, proses dan konteks yang sangat tinggi dalam selfdirected learning. Secara terperinci, dimensi selfdirected learning wanita karir di Kota Tasikmalaya akan dibahas sebagai berikut.

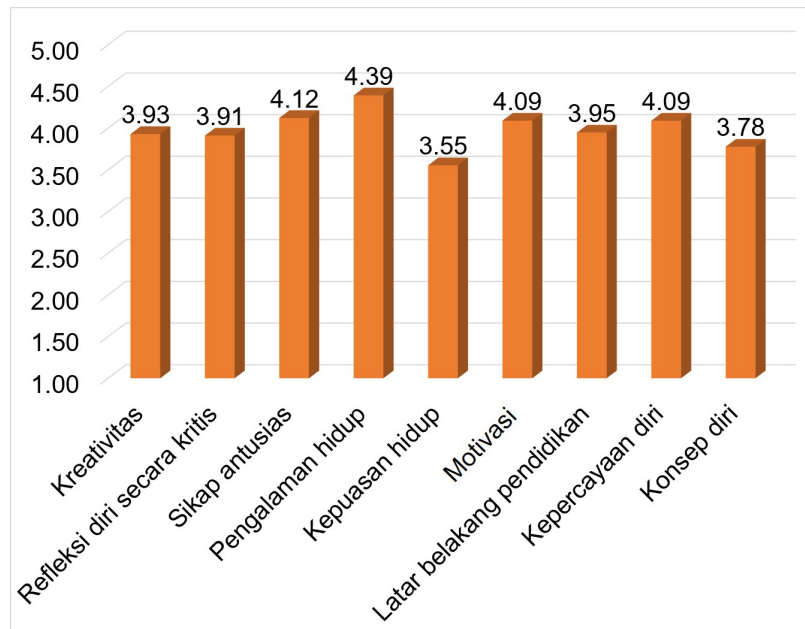

Gambar 4. Rata-Rata Perolehan Skor Dimensi Person pada Variabel Self-Directed Learning Wanita Karir di Kota Tasikmalaya

Berdasarkan gambar 4 di atas dapat diketahui bahwa indikator dari dimensi person yang paling tinggi adalah dorongan dari indikator pengalaman hidup $(4,39)$ diikuti oleh sikap antusias $(4,12)$ dan motivasi serta kepercayaan diri $(4,09)$. Sedangkan faktor yang paling rendah adalah tingkat kepuasan hidup wanita karir. Hal ini menunjukkan bahwa pembelajaran mandiri yang dilakukan oleh wanita karir sebagian besar didorong oleh pengalaman hidupnya, sikap antusias pada pembelajaran, motivasi dan kepercayaan diri. Keempat hal ini merupakan faktor yang berasal dari dalam diri wanita karir (faktor intrinsik), yang merupakan faktor yang muncul atas dorongan diri. Pengalaman hidup wanita menjadi faktor yang berpengaruh pada keberlangsungan belajar mandiri sehingga membuat wanita karir menggunakan pengalaman hidupnya agar selalu melakukan belajar secara mandiri. Hal ini bermakna bahwa proses belajar mandiri akan terlaksana dengan baik jika wanita karir memiliki motivasi, antusias, konsep diri, kepercayaan diri dan kreativits yang tinggi untuk berusaha menjadi wanita yang profesional dalam bekerja dan menjadi ibu rumah tangga yang profesional. Pengalaman hidup baik yang dialami oleh diri sendiri ataupun orang lain merupakan modal utama supaya wanita memiliki softskill untuk melakukan proses belajar secara mandiri. Hal yang tidak kalah penting bagi wanita karir untuk mengembangkan potensinya adalah kemampuan refleksi diri secara kritis. Melalui refleksi kritis, wanita karir mampu memahami kelebihan dan kekurangan yang dimiliki oleh dirinya sampai kepada bagaimana wanita karir merefleksi cara untuk mengatasi atau meminimalisir kelemahan mereka.

Selanjutnya jika dilihat dari dimensi proses $S D L$ wanita karir, kemampuan mengevaluasi dirinya sangat tinggi. Hal ini dibuktikan dengan gambar 5 di bawah ini:

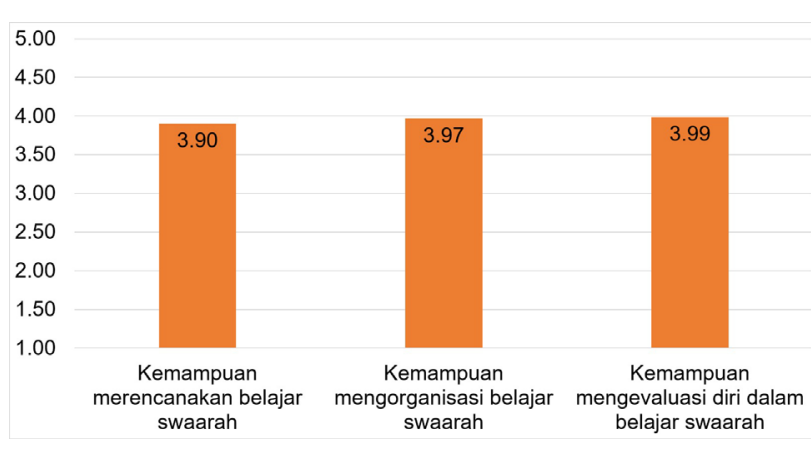

Gambar 5. Rata-rata Perolehan Skor Dimensi Proses pada Variabel Self-Directed Learning Wanita Karir di Kota Tasikmalaya

Berdasarkan gambar 5 diperoleh informasi bahwa dimensi proses $S D L$, wanita karir di Kota Tasikmalaya memiliki kemampuan mengevaluasi diri $(3,99)$, kemampuan mengorganisasi $(3,97)$ 
dan kemampuan merencanakan $(3,90)$. Tiga hal ini merupakan proses yang mengarahkan wanita karir untuk selalu berusaha memenuhi kebutuhan belajarnya. Kemampuan merencanakan, mengorganisasikan dan mengevaluasi diri dalam belajar mandiri menggambarkan bahwa wanita karir di Kota Tasikmalaya memiliki strategi yang digunakan untuk mengarahkan dirinya sendiri. Hal ini memperkuat temuan sebelumnya bahwa dimensi proses melibatkan transaksi belajar-mengajar, termasuk fasilitasi keterampilan belajar, gaya belajar, perencanaan, pengorganisasian, dan evaluasi diri, serta kemampuan teknologi (Hiemstra \& Brockett, 2012, hlm. 158). Selain itu dilihat pada dimensi konteks variabel SDL wanita karir di Kota Tasikmalaya menunjukkan bahwa budaya dan lingkungan belajar sangat mempengaruhi proses belajar mandiri yang dilakukan. Hal ini dibuktikan dengan gambar 6 di bawah ini:

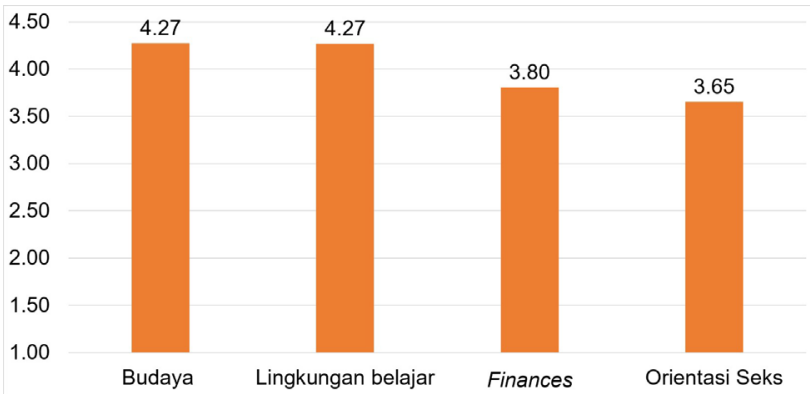

Gambar 6. Rata-rata Perolehan Skor Dimensi Konteks pada Variabel Self-Directed Learning Wanita Karir di Kota Tasikmalaya

Berdasarkan gambar 6 di atas dapat diketahui bahwa wanita karir di Kota Tasikmalaya memiliki dukungan konteks yang tinggi pada budaya dan lingkungan belajar $(4,27)$ walaupun dukungan finances dan kebutuhan orientasi seksnya juga cukup tinggi. Artinya bahwa dimensi konteks dalam hal ini memiliki peran penting dalam menciptakan dan mengatur iklim dalam pembelajaran wanita karir di Kota Tasikmalaya. Dimensi konteks, sebagaimana yang dijelaskan oleh Hiemstra \& Brockett (2012), bahwa dimensi tersebut dalam SDL mencakup lingkungan dan sosiopolitik, misalnya budaya, kekuasaan, lingkungan belajar, keuangan, gender, iklim belajar, kebijakan organisasi, lingkungan politik, ras, dan orientasi seksual. Hal ini menunjukkan bahwa dimensi konteks merupakan pengaruh yang muncul dari luar diri wanita karir.

\section{Structural Output dan Interpretasi Hasil Pengujian Pengaruh Dimensi X1 (Person) dan X2 (Konteks) terhadap Y (Proses)}

Pengujian koefisien determinasi dari analisis jalur dapat dilihat pada tabel 9 berikut ini:
Tabel 9.

Model Summary Koefisien Determinasi

\begin{tabular}{lrr}
\hline R & $.811 a$ \\
R Square & .658 \\
Adjusted R Square & .651 \\
Std. Error of the Estimate & 333.416 \\
& R Square Change & .658 \\
Change & F Change & 93.401 \\
Statistics & df1 & 2 \\
& df2 & 97 \\
& Sig. F Change & .000 \\
\hline
\end{tabular}

a. Predictors: (Constant), X2,X1

Diketahui bahwa koefisien determinasi untuk model $1 \mathrm{R}^{2}$ adalah 0,658 atau sebesar $65,8 \%$. Hal ini mengandung makna bahwa terdapat pengaruh yang besar antara person dan context dalam proses belajar mandiri wanita karir di Kota Tasikmalaya.

Tabel 10.

Penghitungan ANOVA

\begin{tabular}{lrrrrr}
\hline Model & $\begin{array}{c}\text { Sum of } \\
\text { Squares }\end{array}$ & Df & $\begin{array}{c}\text { Mean } \\
\text { Square }\end{array}$ & F & Sig. \\
\hline Regression & 2076.597 & 2 & 1038.299 & 93.401 & $.000^{a}$ \\
1 Residual & 1078.313 & 97 & 11.117 & & \\
Total & 3154.910 & 99 & & & \\
\hline
\end{tabular}

a. Predictors: (Constant), X2, X1

b. Dependent Variable: $Y$

Berdasarkan hasil analisis di atas, diperoleh informasi bahwa model $1, \mathrm{Fo}=93,401 ; \mathrm{db} 1=2$; dan $\mathrm{db} 2=97, \mathrm{p}$-value $=0,000<0,05$ atau H0 ditolak. Dengan demikian, secara simultan variabel person dan konteks berpengaruh terhadap variabel proses self-directed learning.

Tabel 11.

Coefficients

\begin{tabular}{|c|c|c|c|c|}
\hline \multirow{2}{*}{ Model } & & \multicolumn{3}{|c|}{1} \\
\hline & & Constant & $\mathrm{X} 1$ & $\mathrm{X} 2$ \\
\hline \multirow{2}{*}{$\begin{array}{l}\text { Unstandardized } \\
\text { Coefficients }\end{array}$} & $B$ & 1.950 & .233 & .806 \\
\hline & $\begin{array}{l}\text { Std. } \\
\text { Error }\end{array}$ & 2.858 & .088 & 120 \\
\hline $\begin{array}{l}\text { Standardized } \\
\text { Coefficients }\end{array}$ & Beta & & 241 & .613 \\
\hline$T$ & & .682 & 2.648 & 6.719 \\
\hline \multirow[t]{2}{*}{ Sig. } & & .497 & .009 & .000 \\
\hline & $\begin{array}{l}\text { Zero- } \\
\text { order }\end{array}$ & & .706 & .796 \\
\hline \multirow[t]{2}{*}{ Correlations } & Partial & & .260 & .157 \\
\hline & Part & & .564 & .399 \\
\hline
\end{tabular}

a. Dependent Variable: $Y$

Model pengolahan data koefisien jalur yang ditunjukkan.

a. P2.1 $=0,241, p$-value $=0,009 / 2=0,00045<0,05$ atau $\mathrm{H} 0$ ditolak, yang berarti terdapat pengaruh

VISI : Jurnal IImiah PTK PNF - Vol. 15 No. 1, Juni 2020 
antara dimensi person (X1) terhadap dimensi proses (X2).

b. $P 2 \cdot 3=0,613$, p-value $=0,000 / 2=0,000<0,5$ atau $\mathrm{H} 0$ ditolak, yang berarti terdapat pengaruh antara dimensi konteks (X3) terhadap dimensi proses (X2)

Dari analisis ini terlihat bahwa ternyata koefisien jalur (P12 dan P32) hasilnya signifikan sehingga tidak perlu dilakukan trimming. Dengan demikian secara simultan variabel X1 (Person) dan X3 (Konteks) berpengaruh terhadap X2 (Proses). Sehingga hasil dari koefisien jalur dapat digambarkan pada diagram berikut ini:

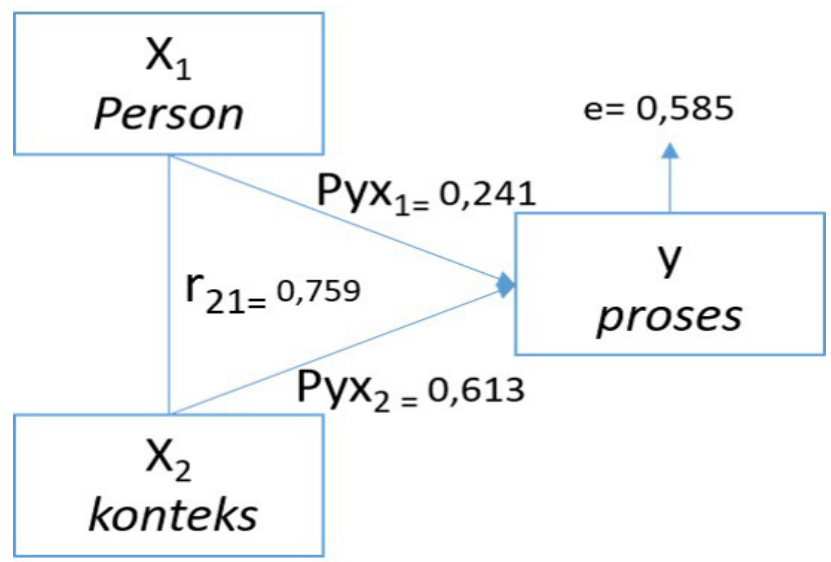

Gambar 7. Skor Koefisien Jalur Hasil Perhitungan

Besarnya pengaruh tiap dimensi secara proporsional dapat dilihat pada tabel 12 di bawah ini:

Tabel 12.

Besarnya Pengaruh Secara Proporsional

\begin{tabular}{|c|c|}
\hline \multicolumn{2}{|c|}{ Pengaruh X1 } \\
\hline Pengaruh langsung & $\begin{array}{l}=p_{y x} \times p y x_{1} \\
=0,241 \times 0,241 \\
=0,058\end{array}$ \\
\hline Pengaruh melalui hub $x_{2}$ & $\begin{array}{l}=\operatorname{pyx}_{1} \times \mathrm{rx}_{2} \mathrm{x}_{1} \times \mathrm{pyx}_{2} \\
=0,241 \times 0,759 \times 0,613 \\
=0,112\end{array}$ \\
\hline Pengaruh $\mathrm{px}_{2} \mathrm{x}_{1}$ & $=0,17$ \\
\hline \multicolumn{2}{|c|}{ Pengaruh X2 } \\
\hline Pengaruh langsung & $\begin{array}{l}=p_{y x} \times p y x_{2} \\
=0,613 \times 0,613 \\
=0,376\end{array}$ \\
\hline Pengaruh melalui hub $x_{1}$ & $\begin{array}{l}=p_{y x} \times r r_{2} x_{1} \times p_{1} x_{2} \\
=0,241 \times 0,759 \times 0,613 \\
=0,112\end{array}$ \\
\hline Pengaruh pyx ${ }_{2}$ & $=0,488$ \\
\hline $\begin{array}{l}\text { Pengaruh Gabungan } X_{1} \\
\text { dan } X_{2}\end{array}$ & $=0,17+0,488=\mathbf{0 , 6 5 8}$ \\
\hline
\end{tabular}

Dari tabel 12 di atas dapat diketahui bahwa harga gabungan pengaruh $\mathrm{X} 1$ dan $\mathrm{X} 3$ terhadap $\mathrm{X} 2$ tidak lain adalah koefisien determinasi, yakni 0,658.
Berdasarkan hasil pengujian analisis jalur pengaruh dimensi person dan context terhadap proses SDL, maka yang paling berpengaruh terhadap proses SDL adalah konteks yakni sebesar $61,3 \%$, sedangkan person hanya $24,1 \%$. Hal ini menunjukkan bahwa kesuksesan wanita karir dalam pengembangan profesionalisme kerjanya disamping sebagai ibu serta istri dipengaruhi lebih besar oleh konteks atau dalam hal ini adalah motivasi ekstrinsik dibandingkan dengan motivasi intrinsik. Motivasi ekstrinsik merupakan motivasi yang berasal dari luar diri wanita karir seperti budaya, lingkungan belajar, kebijakan pemerintah, kebijakan organisasi, situasi politik, ekonomi, ras, dan gender.

\section{Pembahasan}

Berdasarkan pada hasil analisis jalur pengaruh dimensi person $(x 1)$ dan dimensi konteks ( $x 3$ ) terhadap proses belajar mandiri $(x 2)$ dapat diketahui dari model summary koefisien determinasinya yakni sebesar 0,658 atau $65,8 \%$. Hal ini berarti bahwa proses belajar mandiri yang dilakukan oleh wanita karir sangat dipengaruhi oleh personal dan dukungan konteks. Pada wanita karir, pengaruh dimensi konteks atau dukungan budaya keluarga, lingkungan belajar, keuangan dan kebutuhan pribadi wanita karir sangat menunjang terlaksananya proses belajar mandiri. Hal ini juga bermakna bahwa walaupun motivasi diri pada wanita karir tinggi namun tanpa dukungan dan budaya keluarga untuk melakukan proses belajar mandiri, maka tidak akan terjadi proses belajar mandiri yang maksimal oleh wanita karir.

Penelitian tahun 2010 yang dilakukan pada perempuan pengusaha anggota IWAPI menyatakan bahwa dukungan dan izin suami merupakan faktor pendukung utama bagi istri pengusaha. Namun, tidak semua suami berminat melakukannya karena terkait dengan mitos dan budaya yang masih mengacu pada kehidupan perempuan sebagai seorang istri, ibu dan pengasuh anak dimana rumah adalah tempat yang tepat bagi mereka (Hubies, $2010 \mathrm{hlm}$. 364).

Peran dan kontribusi orang terdekat sangat berpengaruh besar pada kualitas kemajuan kualitas diri perempuan. Beberapa penelitian terdahulu melaporkan bahwa ibu yang bekerja memiliki stres individu yang lebih tinggi karena menghadapi konflik pekerjaan-keluarga, keterlibatan kerja, dan kepuasan hidup yang lebih rendah daripada ayah yang bekerja (Kmec, 2011). Oleh karena itu dukungan terdekat dari keluarga sangat dibutuhkan oleh wanita karir guna mengembangkan profesionalitasnya dalam pekerjaan maupun peran domestiknya.

Wanita karir memiliki kecenderungan harapan yang tinggi pada keluarga dalam mendukung profesi 
yang dia lakukan terutama dukungan dari suami, sebelum ia mengambil tanggung jawab dalam pemenuhan kebutuhan belajarnya. Temuan dalam penelitian ini konsisten dengan penelitian sebelumnya bahwa dukungan keluarga yang lebih besar bagi ibu yang bekerja merupakan faktor kunci dalam mengurangi stres pengasuhan yang terbatas (Hwang, 2018). Oleh karena itu pemahaman gender dalam keluarga dirasa sangat diperlukan. Misalnya persepsi mengenai wanita karir, pembagian tanggung jawab dalam mengurus rumah tangga, pemahaman kewajiban dan tanggung jawab terhadap anak, persamaan hak untuk belajar dan mendapatkan pendidikan. Sebesar apapun dukungan suami dalam menciptakan belajar mandiri wanita karir, tidak akan berjalan dengan baik apabila wanita karir tersebut tidak faham mengenai persepsi dan hak yang berkaitan dengan gender, begitupun sebaliknya. Hal ini menegaskan bahwa untuk mewujudkan keberhasilan kesetaraan gender di masyarakat diperlukan kontribusi, dukungan, dan partisipasi aktif dari pihak laki-laki (European Commission, 2011).

Tidak dapat dipungkiri bahwa wanita yang bekerja, memiliki waktu yang kurang memadai untuk memenuhi hak-hak anak dan keluarga, sehingga dibutuhkan kesepakatan bersama dalam keluarga mengenai tugas dan tanggung jawab antara suami dan istri dalam membangun ketahanan keluarga. Selain itu, yang tidak kalah penting adalah komitmen pemerintah dan perusahaan atau tempat bekerja yang mempekerjakan wanita, harus lebih menyadari tentang arti penting ibu dalam keluarga untuk anak-anaknya. Ibu sebagai madrasah pertama dan utama bagi anak selayaknya dipertimbangkan dalam menentukan beban kerja dan waktu kerja wanita karir yang akan berimbas pada mempersiapkan generasi muda yang unggul.

Hasil penelitian awal di pengadilan agama Kota Tasikmalaya diketahui gambaran kasus perceraian di Kota Tasikmalaya pada Tahun 2017 dan 2018 sebagai berikut:

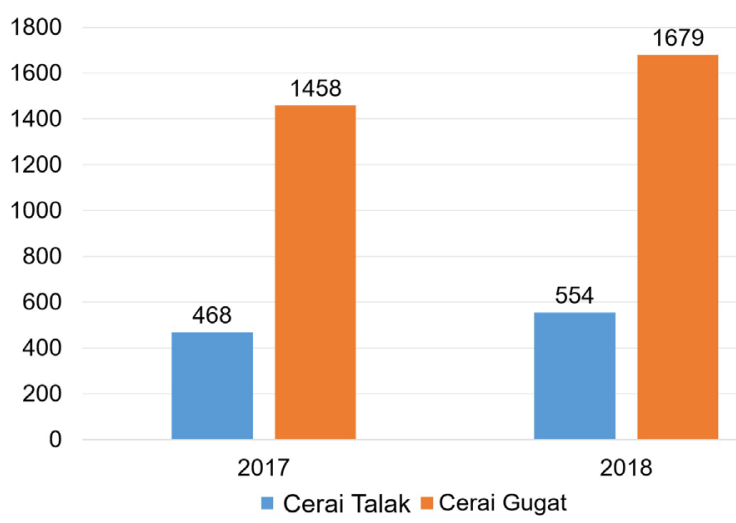

Gambar 8. Jumlah Kasus Perceraian di Kota Tasikmalaya pada Tahun 2017/2018
Berdasarkan pada data di atas dapat diketahui bahwa pada tahun 2017, terdapat 468 kasus cerai talak dan bertambah sebanyak 86 kasus pada tahun 2018 menjadi 554 kasus. Kasus perceraian yang paling mencengangkan adalah cerai gugat. Pada tahun 2017 dan 2018 banyak istri yang menggugat suami dibandingkan suami yang menggugat istri. Pada tahun 2017 terdapat 1458 kasus cerai gugat dan bertambah sebanyak 221 kasus perceraian menjadi 1679 kasus pada tahun 2018. Kasus perceraian ini menjadi ironi, karena tahun 2017 para ibu rumah tangga dapat dengan mudah untuk mencari pekerjaan dan berpenghasilan sehingga dapat meningkatkan kesejahteraan keluarga mereka. Namun ternyata bahwa kemudahan akses ibu rumah tangga pada pekerjaan justru berbanding terbalik dengan banyaknya kasus cerai gugat.

Faktor penyebab perceraian yang terjadi diperinci dengan gambar berikut ini:

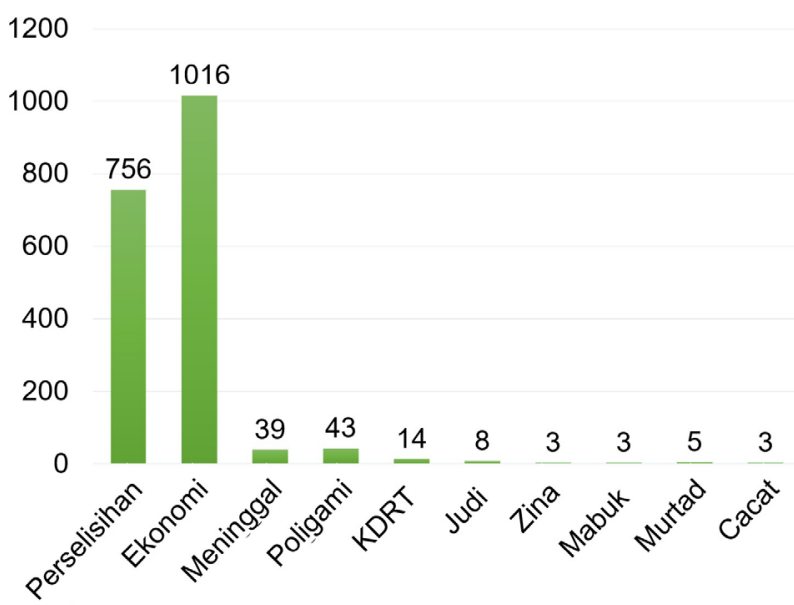

Gambar 9. Faktor Penyebab Perceraian di Kota Tasikmalaya Tahun 2018

Gambar 9 di atas menunjukkan bahwa faktor penyebab perceraian di Kota Tasikmalaya pada Tahun 2018 yang paling banyak adalah karena kasus ekonomi yakni sebanyak 1016 dan perselisihan terus menerus sebanyak 756 kasus. Data ini menunjukkan ada hal yang tidak sinkron, antara kasus perceraian khususnya kasus gugat cerai dengan mudahnya akses perempuan terhadap pendidikan dan pekerjaan. Di satu sisi perempuan mendapatkan kemudahan akses pendidikan dan pekerjaan sehingga dapat membantu perekonomian keluarga. Di sisi lain kemudahankemudahan akses tersebut telah menyita waktu, pikiran dan tenaga para wanita sebagai ibu rumah tangga untuk melayani kewajiban utamanya sebagai istri dan seorang ibu. Kemudahan akses wanita terhadap pekerjaan disebabkan oleh persepsi perusahaan karena wanita mudah untuk dikendalikan (bekerja di bawah tekanan); upah kerja yang murah dengan hasil yang maksimal karena wanita memiliki kelebihan dari 
segi ketelitian dan ketekunan dalam bekerja. Di sisi lain akses untuk laki-laki terhadap pekerjaan menjadi lebih sulit karena banyak persaingan yang ketat bukan hanya dengan sesama laki-laki tetapi juga wanita dengan kompetensi yang dimilikinya.

Hal yang menarik adalah ketika perempuan memiliki posisi yang baik di perusahaan tempat bekerja, atau tempat bekerja yang ketat dalam hal waktu dan target yang mengharuskan wanita bekerja secara lembur berdampak negatif bagi perkembangan rumah tangga, terlebih pada usia produktif dan telah memiliki anak. Kondisi yang terjadi saat ini adalah ketika posisi tawar wanita dalam pekerjaan dan penghasilan lebih tinggi, mengharuskan lakilaki sebagai kepala keluarga mengambil keputusan yang sulit, yakni keluar dari pekerjaan karena alasan pengasuhan anak. Kondisi yang tak lazim dari kejadian seperti ini kemudian menjadi hal yang umum, namun berdampak pada ketahanan keluarga.

Kasus-kasus di atas, selayaknya dapat diminimalisir dengan kemampuan belajar mandiri bagi wanita karir. Belajar mandiri atau self-directed learning bukan hanya sebagai kemampuan tapi juga merupakan softskill yang harus dimiliki oleh wanita karir yang ingin sukses dalam berkarir dan memiliki ketahanan keluarga.

Oleh karena itu, lingkungan organisasi atau tempat kerja dan pemerintah harus duduk bersama memikirkan solusi bagi wanita atau ibu yang bekerja supaya para wanita memiliki waktu untuk belajar mandiri; memiliki waktu untuk menjadi ibu dan istri yang baik dalam membentuk generasi muda yang unggul yang bebas dari kasus LGBT yang marak berkembang karena kesibukan orang tua dalam pekerjaan, sehingga menelantarkan pengasuhan anak. Menjadikan tempat bekerja sebagai tempat bekerja yang ramah ibu, salah satu contohnya perusahaan atau tempat bekerja selayaknya memiliki fasilitas tempat penitipan anak, supaya ibu yang bekerja nyaman meninggalkan anak ketika bekerja, namun juga mereka mampu mengawasi anak mereka di tempat bekerja; fasilitas pumping dan tempat kerja ramah anak. Peraturan Menteri Pemberdayaan Perempuan dan Perlindungan Anak (Permen PPPA) Nomor 5 Tahun 2015 tentang
Penyediaan Sarana Kerja yang Responsif Gender dan Peduli Anak di Tempat Kerja secara tersirat menggambarkan bahwa ketika tugas dan tanggung jawab sebagai istri dan ibu dalam tumbuh kembang anak telah aman, maka ibu yang bekerja atau wanita karir akan mampu mengelola kegiatan belajar mandiri dengan baik sehingga dia mampu menjadi pegawai yang profesional.

Tempat kerja tidak hanya dilihat dari segi fisik dengan bangunannya saja, tetapi juga interaksi tiap pimpinan, karyawan dan rekan usaha yang sangat mempengaruhi kemampuan belajar mandiri. Baik pimpinan, karyawan maupun rekan kerja dapat saling membelajarkan untuk memenuhi kebutuhan belajarnya sesuai tanggung jawab yang diberikan. Murad et.al (2010) melaporkan hasil penelitiannya bahwa pembelajaran mandiri memungkinkan setiap pekerja untuk tetap up-to-date. Hal ini menunjukkan bahwa pentingnya dukungan dari lingkungan organisasi dan kebijakan pemerintah dalam mendukung terlaksanakannya pembelajaran mandiri. Pada umumnya instansi perusahaan yang baik akan senantiasa meningkatkan kemampuan belajar mandiri karyawan atau setiap komponen yang ada dalam suatu organisasi baik melalui pendelegasian untuk mengikuti berbagai penelitian untuk pengembangan karir. Hal lain pada umumnya perusahaan memberikan reward bagi karyawan yang memiliki kinerja terbaik dan punishment bagi karyawan yang memiliki kinerja buruk.

Dilihat dari kemampuan wanita karir dari segi evaluasi hasil belajar dan refleksi kritis, wanita karir lebih dapat melakukan evaluasi diri dibandingkan dengan mengorganisasikan pembelajarannya. Mereka mampu menganalisis kemampuan dari hasil belajarnya dan mampu mengaplikasikan hasil belajar yang dilakukan untuk mengatasi masalah hidup dan pekerjaannya. Melalui kemampuan evaluasi dan refleksi kritis belajar mandiri yang dilakukan mereka dapat mengetahui tingkat pencapaian tujuan belajarnya, manajemen diri, mengembangkan strategi yang tepat untuk kegiatan pengembangan karir, meningkatkan pendapatan, menjadi ibu sekaligus seorang istri yang bertanggung jawab dengan perannya di dalam keluarga.

\section{PENUTUP}

\section{Simpulan}

Beberapa simpulan dalam penelitian ini, yakni:

a. Wanita karir di Kota Tasikmalaya dapat memiliki atribut personal bagus jika ditopang oleh dukungan konteks yang memadai, sehingga dapat menunjang proses belajar mandiri baik untuk pengembangan karir maupun perannya sebagai istri dan ibu.

b. Dukungan konteks khususnya dukungan keluarga, pemerintah dan kebijakan organisasi 
menjadikan wanita karir termotivasi untuk senantiasa belajar mandiri dalam upaya meningkatkan profesionalisme kerja dan menjaga ketahanan keluarganya.

c. Wanita karir di Kota Tasikmalaya mampu mengevaluasi diri namun belum dapat melakukan proses belajar mandiri secara efektif dan efisien, karena ia belum mampu memanfaatkan dukungan konteks dan motivasi dirinya.

d. Terdapat beberapa variabel lain yang mempengaruhi belajar mandiri perempuan diantaranya variabel yang berkaitan dengan minat dan bakat, intelegent quotient, spiritual quotient, multiple intelegent, akses yang berkaitan dengan infrastruktur.

\section{Saran}

Atas kesimpulan tersebut maka rekomendasi atau saran dalam penelitian ini adalah sebagai berikut:

a. Perlu adanya dukungan dan kerjasama dari pihak keluarga, instansi dan pemerintah dalam memfasilitasi kegiatan belajar mandiri yang dilakukan oleh wanita karir;

b. Perlu adanya penataan serius terkait kebijakan instansi dan pemerintah yang mendukung Peran ganda wanita karir sebagai pekerja maupun sebagai ibu dan istri.

c. Supaya wanita karir memiliki kemampuan self-directed learning, maka dibutuhkan beban kerja yang sesuai dengan waktu untuk pemenuhan hak anak dan keluarga sehingga tidak berdampak pada masalah sosial seperti kerentanan keluarga dan kasus LGBT.

d. Pemerintah dan perusahaan selayaknya duduk bersama membuat kebijakan membangun fasilitas tempat bekerja ramah ibu dan anak (misalnya tempat penitipan anak, ruang ramah anak, ruang pumping) sehingga ketika ibu merasa aman dengan tugas di keluarganya, maka ia akan menjadi lebih profesional dalam bekerja.

\section{DAFTAR PUSTAKA}

Arcarons, A. F. (2018). The working mother-in-law effect on the labour force participation of first and second-generation immigrant women in the UK, Journal of Ethnic and Migration Studies, DOI: 10.1080/1369183X.2018.1539268.

Attard, A., Di loio, E., Geven, D., \& Santa, R. (2010). Student centered learning: An insight into theory and practice. Bucharest, Romania: Education and Culture GD. Available at http:// www.ehea.info/media.ehea.info/file/T4SCL_ forum_Leuven_October_2010/34/2/2010_ T4SCL_Stakeholders_Forum_Leuven_An_ Insight_Into_Theory_And_Practice_600342.p df. Accessed 02 Mei 2020.

Ayyildiz, Y., \& Tarhan, L. (2015). Development of the self-directed learning skills scale, International Journal of Lifelong Education, DOI: 10.1080/02601370.2015.1091393.

Bijker, M. M., Van der Klink, M. R., \& Boshuizen, H. P. A. (2010). Modelling self-efficacy, self-regulation, self-directed learning and career processes of adult professionals and relations with learning outcomes and labour market success. Paper presented at the $5^{\text {th }}$ EARLI-SIG14 Learning Professional Development, Munich, Germany.

BPS. (2018). Keadaan Ketenagakerjaan Indonesia. Tersedia [Online]: https://www.turc.or.id/wpcontent/uploads/2018/06/BPS_Berita-Resmi-
Statsitik_Keadaan-Ketenagakerjaan-IndonesiaFebruari-2018.pdf. Accessed 13 November 2019.

Douglass, C., \& Morris, S. R. (2014). Student perspectives on self-directed learning. Journal of the Scholarship of Teaching and Learning, 14(1):13-25. https://doi.org/10.14434/josotl. v14i1.3202

European Commission. (2011). 'Strategy for Equality Between Women and Men 2010/2015', Luxembourg: Publications Office of the European Union, www.ec.europa.eu/social/ BlobServlet?docld6568\&langlden (last checked by the author 11 January 2013).

Gilbert, N., \& Terrell, P. (2013). Dimensions of social welfare policy. New Jersey, NY: Pearson Education.

Guglielmino, L. M. (2013). The case for promoting self-directed learning in formal educational institutions. SA-eDUC Journal, 10(2):1-18. Available at https://www.nwu.ac.za/sites/www. nwu.ac.za/files/files/psaeduc/sdl\%20issue/ Guglielmino,\%20L.M. \%20The $\% 20$ case $\% 20$ for $\% 20$ promoting $\% 20$ selfdirected\%20lear.pdf. Accessed 17 Mei 2019.

Hiemstra, R., \& Brockett, R. G. (2012). Reframing the meaning of self-directed learning. Adult Education Research Conference Proceedings. 
Retrieved from http://newprairiepress.org/cgi/ viewcontent.cgi?article $=3070$ \&context $=$ aerc

Hubeis. A. V. S. (2010). Pemberdayaan Perempuan dari Masa ke Masa. Bogor: IPB Press.

Hwang, W. (2018). The Effects of FamilyFriendly Policies and Workplace Social Support on Parenting Stress in Employed Mothers Working Nonstandard Hours, Journal of Social Service Research, DOI: 10.1080/01488376.2018.1501790

Imants, J., Wubbels, T., \& Vermunt, J. D. (2013). Teachers' enactments of workplace conditions and their beliefs and attitudes toward reform. Vocations and Learning, 6(3):323-346. https:// doi.org/10.1007/s12186-013-9098-0

Kmec, J. A. (2011). Are motherhood penalties and fatherhood bonuses warranted? Comparing prowork behaviors and conditions of mothers, fathers, and non-parents. Social Science Research, 40(2), 444-459.

Lennon, S. L., \& Heaman, H. (2015). Factors associated with family resilience during pregnancy among inner-city women, Journal of Midwifery, http:// dx.doi.org/10.1016/j.midw.2015.05.007.

Louws, M. L., Meirink, J. A., Van Veen, K., \& Van Driel, J. H. (2017). Teachers' self-directed learning and teaching experience: What, how, and why teachers want to learn. Teaching and Teacher Education, 66:171- 183. https://doi. org/10.1016/j.tate.2017.04.004.

Merriam, S. B., \& Bierema, L. L. (2013). Adult learning: Linking theory and practice. New Jersey: Jossey-Bass, John Wiley \& Sons.
Merriam, S. B., \& Brockett, R. (2007). The Profession and Practice of Adult Education: An Introduction. San Francisco: Jossey-Bass.

Moilanen, S., May, V., Räikkönen, E., Sevón, E., Laakso, M-L. (2016). "Mothers' non-standard working and childcare-related challenges", International Journal of Sociology and Social Policy, Vol. 36 Iss $1 / 2$ pp. 36 - 52 http://dx.doi. org/10.1108/IJSSP-11-2014-0094

Murad, M. H., Coto-Yglesias, F., Varkey, P., Prokop, L. J., \& Murad, A. L. (2010). The effectiveness of self-directed learning in health professions education: A systematic review. Medical Education, 44, 1057-1068.

Murray, H. (2015). Lifelong learning in the twenty-first century: An investigation on the interrelationships between self-directed learning and lifelong learning. Doctor of Education, Union State and University, Cincinati, Ohio.

Park, H., Zhan, M., \& Choi, S. (2019). Associations between afterschool arrangements and labour conditions of low-income working mothers in the United States, Journal of Family Studies, DOI: 10.1080/13229400.2019.1588142

Sevilla, C.G. et. al (2007). Research Methods. Rex Printing Company. Quezon City.

Verster, M., Mentz, E., \& Du Toit-Brits, C. (2018). Requirements of the 21st century for teachers' curriculum as praxis: A theoretical perspective. Literacy Information and Computer Education Journal (LICEJ), 9(3):461-463.

Walsh, K. (2017). Self-directed learning at the point of care. Journal of InnovAiT. DOI: 10.1177/1755738016679441 